\title{
Perilaku Wanita Pekerja Seks Dalam Pencegahan Penyebaran HIV/AIDS Di Kabupaten Tuban
}

\author{
Aris Puji Utami ${ }^{1}$, Kharirotul Fikriyah ${ }^{2}$ \\ ${ }^{1}$ Program Studi D III Kebidanan STIKES Nahdlatul Ulama Tuban \\ ${ }^{2}$ Program Studi S1 Keperawatan STIKES Nahdlatul Ulama Tuban \\ Email : arispuji@stikesnu.com
}

\begin{abstract}
ABSTRAK
Human Imunodeficiency Virus (HIV) and Acquired Imunodeficiency Syndrome (AIDS) merupakan salah satu masalah kesehatan terbesar pada abad 21 sampai saat ini. Kasus HIV/AIDS terus melonjak salah satunya disebabkan adanya praktek prostitusi karena wanita pekerja seks (WPS) merupakan salah satu kelompok resiko tinggi tertular HIV/AIDS.

Desain penelitian ini menggunakan metode penelitian deskriptif kualitatif. Subyek penelitian ini adalah wanita pekerja seks yang menjual jasa seksual dengan imbalan uang yang berada di Dusun Dasin Desa Sugiwaras Kecamatan Jenu Kabupaten Tuban sejumlah lima oranng wanita pekerja seks. Teknik pengumpulan data yang digunakan dalam penelitian ini adalah observasi dan teknik wawancara terstruktur (structured interview).

Hasil penelitian ini menunjukan sebagian besar partisipan melakukan pencegahan penyebaran HIV/AIDS dengan cara penawaran dan penggunaan kondom pada pelanggan, akan tetapi ada beberapa partisipan yang tetap melayani pelanggan meskipun tanpa menggunakan kondom dengan alasan pelanggan tidak mau karena tidak enak dan tidak terasa saat berhubungan, partisipan mengaku tetap melayani pelanggan karena faktor ekonomi yang mereka alami. Dalam hal pengetahuan pencegahan penyebaran HIV/AIDS para partisipan tergolong masih kurang mengetahui dan kurang faham.

Untuk mencegah penyebaran HIV/AIDS para wanita pekerja seks diharapkan selalu menawarkan penggunaan kondom kepada pelanggan, hal ini juga sebagai alat pelindung diri dari berbagai penularan penyakit kepada setiap pelanggan yang mereka layani.
\end{abstract}

Kata Kunci: Perilaku, Wanita pekerja seks, Upaya pencegahan HIV/AIDS.

\section{ABSTRACT}

Human Immunodeficiency Virus (HIV) and Acquired Immunodeficiency Syndrome (AIDS) is one of the biggest health problems of the 21 st century to the present. HIV/AIDS cases are sharply increasing due to the prostitution. In this case women are particularly vulnarable to being exposed to HIV/AIDS.

The design of research used qualitative descriptive research method. The subjects of this study were female sex workers selling sexual services in exchange for money in the Dasin Village of Sugiwaras Village, Jenu District, district of Tuban, five female sex workers. Data collection techniques used in this study are observation and structured interview techniques (structured interview).

The results showed the majority of the participants were doing the prevention of the spread of HIVIAIDS with the way the deals and the use of a condom on the customers. However, there are some participants were still serve customers though without used a condom because the customers feel not good and feel uncomfortable when did sex. The participants still did it because factor economic that they experinced. In terms of prevention 
knowledge of the spread of HIV/AIDS, the participants are still less aware and less understood.

To prevent the spread of HIV / AIDS women sex workers are expected to always offer condom use to customers, as well as a personal protective tool from disease transmission to every customer they serve.

Keywords: Attitude, Female Sex Workers, HIV/AIDS Prevention.

\section{PENDAHULUAN}

Saat ini tingkat kemoralan bangsa Indonesia semakin terpuruk, hal ini terbukti dengan tingginya jumlah pekerja seks komersial, akibatnya semakin banyak ditemukan penyakit menular seksual. Pekerja seks komersial dibagi menjadi pekerja seks pria dan pekerja seks wanita (Putra dkk, 2015). Wanita pekerta seks yang menjadi faktor penting di dalam penyebaran HIV/AIDS yang tidak dapat dipisahkan dengan kondisi prostitusi yang cukup eksis di Indonesia (Widyastuti, 2009). Biasanya HIV/AIDS ini sebagian besar di idap oleh wanita pekerja seks, dimana dalam "menjajakan" dirinya dengan pasangan kencan atau pelanggan yang ganti-ganti. Tidak hanya wanita pekerja seks saja yang menyumbang HIV/AIDS tetapi pelanggannya juga merupakan penyebab penyebaran HIV/AIDS karena melakukan perilaku seksual yang tidak aman tanpa menggunakan kondom antara wanita pekerja seks dengan pelanggan. Wanita pekerja seks menyumbang 5,9\% sebagai kelompok beresiko terinfeksi HIV/AIDS (Dirjen PPM \& PL Kemenkes RI, 2010 dalam Dwi, E.P. 2012).

\section{Human Imunodeficiency Virus}

(HIV) and Acquired Imunodeficiency Syndrome (AIDS) merupakan salah satu masalah kesehatan terbesar pada abad 21 ini. Setidaknya ada 24,2 juta orang yang hidup dengan HIV 2,5 juta infeksi baru dan 1,7 juta kematian yang diakibatkan oleh AIDS di seluruh dunia (WHO, 2010). Sejak pertama kali ditemukan tahun 1987 sampai dengan maret 2016, HIV/AIDS tersebar di 407 (80\%) dari 507 kabupaten/kota di seluruh provinsi di Indonesia. Di Jawa Timur terdapat 1,614 kasus HIV sedangkan kasus AIDS di sebanyak 673 yang di laporkan sampai dengan tahun 2017. Di Kabupaten Tuban jumlah HIV sebanyak 22 kasus dan jumlah AIDS sebanyak 560 kasus (Kemenkes RI, 2017).

Kasus HIV/AIDS terus melonjak salah satunya disebabkan adanya praktek prostitusi karena wanita pekerja seks (WPS) merupakan salah satu kelompok risiko tinggi tertular HIV/AIDS. Berdasarkan Keputusan Menteri Koordinator Kesejahteraan Rakyat No.9 tahun 1994, salah satu sasaran Komunikasi Informasi dan Edukasi (KIE) penanggulangan HIV/AIDS adalah kelompok berisiko tinggi yaitu orangorang yang pekerjaannya menyebabkan mereka menghadapi kemungkinan atau risiko lebih tinggi untuk tertular dan menularkan HIV/AIDS salah satunya adalah para wanita pekerja seks. Dari hasil survei awal yang di lakukan melalui wawancara pada wanita pekerja seks di Dusun Dasin Desa Sugiwaras Kecamatan Jenu Kabupaten Tuban pada bulan November 2017 di dapatkan salah satu dari wanita pekerja seks menyatakan bahwa sebagian besar para pelanggan menolak menggunakan kondom saat berhubungan seks dengan alasan tidak enak dan tidak terasa saat berhubungan seks, dalam arti lain kenikmatan yang di rasakan pelanggan akan berkurang.

Koentjoro (1995) dalam Budiman (2008) mengemukakan bahwa sebagian besar penularan HIV/AIDS disebabkan 
oleh prostitusi $(49,8 \%)$. Selain itu, perilaku menyimpang dari WPS, homoseks, dan pengguna narkoba suntik yang saling bergantian juga menyebabkan kasus HIV/AIDS terus melonjak. Wanita pekerja seks bekerja dalam berbagai macam bentuk. Mereka dapat bekerja di lokalisasi terdaftar dibawah pengawasan medis (direct sex workers) atau dapat juga sebagai wanita pekerja seks tidak langsung (indirect sex workers). Wanita pekerja seksual tidak langsung (indirect sex workers) mendapatkan klien dari jalan atau ketika bekerja di tempat-tempat hiburan seperti club malam, panti pijat, diskotik, cafe, tempat karaoke atau bar (Dandona, 2008). Hubungan seksual dengan bergantiganti pasangan ini tentunya sangat beresiko bagi wanita pekerjasSeks sendiri, selain itu para pelanggan wanita pekeja seks sulit untuk mau berhubungan seks dengan menggunakan kondom sehingga hal ini akan semakin meningkatkan resiko HIV/AIDS pada WPS. Berdasarkan beberapa penjelasan diatas, maka dapat disimpulkan bahwa penularan HIV/AIDS pada kelompok resiko tinggi sudah terkonsentrasi dan menjadi masalah kesehatan masyarakat, hal ini memerlukan penanganan yang serius, komprehensif dan berkesinambungan untuk bisa memutus rantai penularan HIV/AIDS. Saat ini wanita pekerja seks merupakan faktor resiko tinggi terjadinya penularan HIV/AIDS. Sehingga diperlukan suatu pencegahan, salah satunya melalui pemberian informasi menggunakan kondom mulai dari awal sampai akhir hubungan seksual dengan kelompok resiko tinggi tertular HIV/AIDS dan pembangunan paradigma dalam WPS bahwa pendidikan mengenai HIV/AIDS merupakan suatu hal yang sangat penting diketahui (Dandona, 2008).

Dari masalah-masalah tersebut seharusnya perlu diadakannya penyuluhan dari dinas terkait untuk pencegahan HIV/AIDS supaya meningkatkan pengetahuan WPS yang diharapkan bisa membuka pola pikir WPS dan perilaku yang positif untuk melakukan upaya pencegahan terhadap HIV/AIDS.

Berdasarkan hasil latar belakang tersebut, menjadi alasan peneliti melakukan penelitian tentang perilaku wanita pekerja seks dalam pencegahan penularan HIV/AIDS di Kabupaten Tuban.

\section{METODE PENELITIAN}

Metode yang digunakan dalam penelitian ini adalah deskriptif kualitatif yaitu metode penelitian yang berlandaskan pada filsafat postpositivisme, digunakan untuk meneliti pada kondisi obyek yang alamiah (sebagai lawanya dari eksperimen), dimana peneliti adalah sebagai instrumen kunci, teknik pengumpulan data dilakukan secara triangulasi (gabungan), analisis data bersifat induktif atau kualitatif dan hasil penelitian kualitatif lebih menekankan makna daripada generalisasi (Sugiyono, 2015).

Subyek dalam penelitian ini adalah Wanita Pekerja Seks yang menjual jasa seksual dengan tujuan mendapatkan imbalan uang yang berada di Dusun Dasin Desa Sugiwaras Kecamatan Jenu Kabupaten Tuban dengan waktu penelitian yang dilakukan pada tanggal 20-25 Februari 2018.

Instrument penelitian yang digunakan untuk penelitian ini adalah observasi dan wawancara terstruktur (structured interview) dalam menggali informasi lebih mendalam dan kebenarannya dari setiap partisipan.

Dalam penelitian ini menggunakan non probability sampling dengan purposive sampling yaitu teknik pengambilan sampel sumber data dengan pertimbangan tertentu. Pertimbangan tertentu ini, misalnya orang tersebut dianggap paling tahu tentang apa yang kita harapkan, atau mungkin dia sebagai penguasa sehingga akan memudahkan peneliti menjelajahi obyek/situasi sosial yang diteliti (Sugiyono, 2015). 
Proses pengumpulan data pada penelitian ini peneliti meminta data kepada Dinas Sosial Kabupaten Tuban terkait lokasi yang banyak terdapat wanita pekerja seks di Kabupaten Tuban. Setelah mendapat data peneliti mendatangi tempat lokasi, kemudian peneliti akan melakukan penentuan partisipan sesuai dengan kriteria peneliti. Sebelum memulai wawancara peneliti akan melakukan pengamatan lingkungan dan perilaku partisipan. Setelah meneliti perilakunya, peneliti akan membina hubungan saling percaya dengan calon partisipan.

Peneliti akan memperkenalkan diri terlebih dahulu, menjelaskan maksud dan tujuan penelitian. Setelah calon partisipan memahami tujuan dari penelitian yang akan dilakukan dan memahami hak-hak mereka sebagai partisipan, selanjutnya peneliti meminta partisipan untuk menandatangani serta kesediaan berpartisipasi atau informed consent. Namun jika menolak peneliti tidak akan memaksa dan menghormati hak-haknya. Kemudian peneliti membuat kontrak mengenai waktu pelaksanaan wawancara yang disesuaikan dengan kondisi dan kesediaan partisipan.

Pelaksanaan wawancara akan disesuaikan dengan situasi dan kondisi partisipan, dalam proses wawancara peneliti akan menyiapkan panduan topik wawancara. Hasil wawancara akan direkam dengan menggunakan telepon genggam.

Alat perekam berupa telepon genggam, buku catatan dan pedoman wawancara digunakan sebagai alat untuk mengumpulkan data peneliti. Telepon genggam dipilih karena ungkapan pengalaman yang disampaikan oleh partisipan tidak memungkinkan untuk dicatat langsung oleh peneliti. Buku catatan digunakan untuk membuat field note atau catatan lapangan. Field note yang dibuat berisi respon nonverbal yang diekspresikan partisipan ketika menyampaikan pengalamannya tentang budaya yang diteliti, serta untuk mencatat kondisi lingkungan selama proses wawancara.

Wawancara terstruktur (structured interview) dipilih sebagai metode wawancara yang digunakan dalam penelitian ini. Metode ini dipilih karena dapat memberikan kesempatan kepada partisipan untuk mengungkapkan pengalaman mereka. Wawancara akan dilakukan sesuai kontrak yang dibuat saat membina hubungan saling percaya dengan calon partisipan.

Langkah-langkah analisa data dalam penelitian ini yaitu:

1. Periode pengumpulan data

Data diperoleh dari hasil wawancara dan observasi kemudian data dikumpulkan untuk di analisis lebih lanjut.

2. Reduksi Data

Setelah data dikumpulkan kemudian data direduksi. Mereduksi data berarti merangkum, memilih hal-hal yang pokok, memfokuskan hal-hal yang penting, dicari tema dan polanya.

3. Display Data (penyajian data)

Setelah data direduksi kemudian mendisplaikan data. Data disajikan dalam bentuk deskriptif atau teks yang bersifat naratif.

4. Verifikasi atau kesimpulan

Data yang telah didisplai dapat ditarik kesimpulan atau verifikasi. Kesimpulan awal bersifat sementara tetapi apabila didukung oleh bukti-bukti yang valid maka kesimpulan akan akurat.

\section{HASIL DAN PEMBAHASAN Gambaran Umum Penelitian}

Kecamatan Jenu adalah sebuah Kecamatan yang terletak di jalur Pantura, tepatnya $10 \mathrm{~km}$ arah barat dari Kota Tuban. Kecamatan Jenu membawahi 17 Desa, salah satunya adalah Desa Sugihwaras.

Desa Sugihwaras mempunyai 4 Dusun, 8 RW dan 19 RT, di Desa Sugihwaras terdapat lokalisasi yang terkenal dengan nama Dasin. Di lokalisasi Dasin sudah ditutup secara resmi oleh pemerintah setempat, akan tetapi 
penutupan lokalisasi ini belum bebas sepenuhnya dari aktifitas prostitusi, buktinya sampai saat ini masih banyak para wanita pekerja seks yang masih tinggal dan masih aktif dikawasan lokalisasi Dasin, banyak rumah warga sekitar yang dijadikan sebagai tempat kos yang bebas dikawasan lokalisasi Dasin. Tidak hanya itu, banyak juga terdapat penyewaan kamar untuk para wanita pekerja seks dalam melayani pelanggannya dengan tarif hanya 50.000 rupiah dalam sekali berkunjung.

\section{Karakteristik Informan}

Dalam penelitian ini telah dilakukan observasi dan wawancara terstruktur (structured interview) terhadap 5 orang wanita pekerja seks sebagai partisipan masing-masing dipilih secara purposive sampling. Usia wanita pekerja seks dalam rentang 27 tahun hingga 40 tahun, partisipan kebanyakan berstatus cerai dan ada satu partisipan yang berstatus belum menikah. Agama yang dianut oleh semua partisipan adalah islam.

\section{Pengetahuan wanita pekerja seks tentang pencegahan HIV/AIDS}

Berdasarkan hasil wawancara dengan wanita pekerja seks bahwa sebagian besar partisipan mengetahui tentang HIV/AIDS, 4 partisipan mengatkan tahu akan tanda dan gejala, 3 partisipan mampu menjelaskan tentang pencegahan penyakit HIV/AIDS, sebagian besar partisipan tidak melakukan skrining HIV/AIDS dilayanan kesehatan, hanya 1 partisipan yang melakukan skrining HIV/AIDS di Puskesmas Kayu Tanggi Banjarmasin.

Menurut (Riset Kesehatan Dasar Tahun 2010, dalam Yesmin dkk, 2014) Acquired Immunodeficiency Syndrome (AIDS) disebabkan oleh Human Immunodeficiency Virus (HIV) yang menyebabkan melemahnya sistem kekebalan tubuh seseorang, membuatnya lebih rentan terhadap berbagai penyakit, sulit sembuh dari berbagai penyakit infeksi oportunistik dan bisa menyebabkan kematian. Menurut ilmuwan Perancis Montagnier (Institute Pasteur, Paris) (1983) mengisolasi virus dari pasien dengan gejala lamfadenopati dan menemukan virus HIV, sehingga virus ini dinamakan Lymphadenopathy Associated Virus (LAV). Menurut Gallo (National institute of Health, USA) (1984) menemukan virus human $T$ lymphotropic virus (HTLV-111), yang juga menyebabkan AIDS. Menurut (Widoyono, 2008) Pada tuhan 1986 di Afrika ditemukan beberapa tipe HIV, yaitu HIV-1 yang menyerang manusia dan HIV-2 yang ditemukan di Afrika Barat. Virus HIV termasuk subfamily Lentivirinae dari family Retroviridae.

Berdasarkan hasil wawancara penelitian dan teori diatas bahwa sebagian besar para partisipan mengetahui tentang HIV/AIDS, partisipan yang mengetahui tentang penyakit HIV/AIDS memperoleh informasi tersebut dari media internet maupun dari media cetak. Hampir seluruh partisipan mampu menjawab dan menjelaskan tentang penyakit HIV/AIDS, partisipan yang tidak mampu menjawab dikarenakan kuranya pengetahuan yang mereka miliki. Sebagian besar partisipan mampu menyebutkan tanda dan gejala HIV/AIDS seperti berbadan kurus, alat kelamin berbau dan bernanah, sedangkan partisipan yang tidak mengetahui hanya memberikan jawaban tidak tahu. Sebagian besar partisipan mampu menjelaskan tentang pencegahan penyebaran HIV/AIDS, partisipan menjelaskan bahwa cara pencegahan penyebaran HIV/AIDS dengan cara periksa ke dokter dan pemakaian kondom pada pelanggan setiap kali melakukan hubungan seksual. Dari 5 partisipan hanya 1 partsisipan yang melakukan skrining HIV/AIDS di Puskesmas Kayu Tanggi Banjarmasin, partisipan yang melakukan skrining HIV/AIDS adalah partisipan yang mempunyai pengetahuan yang cukup tentang HIV/AIDS sehingga partisipan 
memiliki kesadaran untuk memeriksakan diri ke fasilitas kesehatan seperti puskesmas, sedangkan partisipan yang tidak melakukan skrining HIV/AIDS dikarenakan memiliki pengetahuan yang kurang dan ketakutan terhadap penyakit serta faktor biaya yang dikeluarkan. Dari 5 partisipan 1 partisipan menyatakan melakukan skrining HIV/AIDS di Puskesmas.

Dapat disimpulkan bahwa pengetahuan wanita pekerja seks cukup baik, partisipan mampu menjelaskan cara pencegahan penyebaran HIV/AIDS akan tetapi partisipan enggan melakukan pencegahan tersebut dengan alasan tuntutan ekonomi hal ini berdampak pada perilaku yang negatif pada wanita pekerja seks, yang mana mempunyai risiko yang tinggi pada penularan HIV/AIDS.

\section{PEMBAHASAN}

\section{Perilaku Wanita Pekerja Seks Dalam Pencegahan Penyebaran HIV/AIDS}

Berdasarkan hasil wawancara peneliti mengetahui gambaran perilaku wanita pekerja seks dalam pencegahan penyebaran HIV/AIDS bahwa seluruh partisipan menyatakan rasa takut jika terkena penyakit HIV/AIDS. Dari 5 partisipan rata-rata mereka menjadi wanita pekerja seks sudah 3 tahun. Sedangkan sebagian besar upaya yang dilakukan oleh wanita pekerja seks dalam pencegahan HIV/AIDS salah satunya dengan menawarkan kondom kepada pelanggan. Sebagian besar partisipan tidak melakukan upaya penolakan apabila pelanggan menolak dalam penggunaan kondom. Sebagian besar partisipan tidak yakin akan pelanggan yang tidak terkena HIV/AIDS, 5 dari 4 partisipan diantaranya tidak bisa membuktikan keyakinan tersebut. Hampir seluruh partisipan menyatakan bahwa motivasi terbesar mereka untuk pencegahan HIV/AIDS adalah keluarga mereka.

Hasil penelitian tersebut sependapat dengan penelitian dari Budiono dkk (2010) di Resosialisasi Argorejo Semarang dimana diketahui bahwa beberapa alasan pelanggan tidak mau menggunakan kondom adalah pelanggan merasa tidak enak atau tidak nyaman, kurang puas, serta tidak sedikit dari pelanggan merasa dirinya sehat sehingga tidak perlu menggunakan kondom dalam hubungan seks dengan WPS.

Menurut Robert Kwick (1974) menyatakan bahwa perilaku adalah tindakan atau perbuatan suatu organisme yang dapat diamati dan bahkan dapat dipelajari. Menurut Koentjoro (2004) istilah wanita pekerja seks adalah istilah baru yang mengandung pengertian sama dengan pekerja seks komersial, wanita tuna susila maupun pelacur. Istilah wanita pekerja seks saat ini sering dipakai oleh para pakar, praktisi, dinas kesehatan, aktifis perempuan dan HIV/AIDS untuk mengganti istilah pelacur, dengan pertimbangan istilah ini terasa lebih halus dan terkesan tidak memojokan pekerjaan mereka sebagai pelacur. Lawrence Green menyebutkan bahwa faktor yang mempengaruhi perilaku adalah faktor predisposisi yaitu pengetahuan, faktor pendukung, faktor pendorong, serta faktor lingkungan yaitu kemiskinan, seks bebas, turunan dan broken home.

Berdasarkan hasil wawancara penelitian dan teori diatas dapat disimpulkan bahwa seluruh partisipan menyatakan rasa takut akan kematian terkena HIV/AIDS, dikarenakan pekerjaan mereka yang beresiko tinggi akan penularan penyakit kelamin dan HIV/AIDS, partisipan yang menyatakan takut sebagian besar mengetahui tentang penyebab, tanda dan grejala serta cara penularan penyakit HIV/AIDS. Rata-rata partisipan sudah 3 tahun menjadi wanita pekerja seks dengan dilatarbelakangi oleh faktor ekonomi serta status pernikahan yang gagal yang menjadikan partisipan memilih pekerjaan seperti ini, selain itu riwayat pendidikan pada partisipan yang sebagian besar berpendidikan SMP membuat partisipan tidak memiliki 
alternatif pekerjaan lain yang bisa dilakukan, berkaitan juga dengan tingkat kesadaran dan pengetahuan tentang resiko penyakit yang dapat tertular dari pelangganya. Hampir seluruh partisipan mengetahui bahwa kondom dapat mencegah terjadinya HIV/AIDS, namun kesadaran pelanggan untuk memakain kondom sangat rendah hal ini menjadikan hampir seluruh partisipan tetap melayani pelanggan yang tidak mau memakai kondom. Seluruh partisipan tidak mempercayai bahwa pelanggan mereka tidak terkena HIV/AIDS, partisipan cenderung pasrah dan melayani semua pelanggan tanpa menghiraukan kemungkinan penularan penyakit HIV/AIDS. Sebagian besar partisipan tidak yakin akan pelanggan tidak terkena HIV/AIDS, 5 dari 4 partisipan diantaranya tidak dapat membuktikan ketidakyakinan tersebut. Hampir seluruh partisipan menyatakan motivasi terbesar mereka untuk sadar dalam pencegahan dan penularan penyakit berbahaya seperti HIV/AIDS adalah karena mengingat keluarga.

Dapat disimpulkan bahwa dengan pengetahuan yang rendah pada wanita pekerja seks dalam penularan dan pencegahan penyakit HIV/AIDS semakin meningkatkan resiko tertularnya penyakit tersebut namun pada wanita pekerja seks yang memiliki pengetahuan yang cukup baik dalam pencegahan dan penularan HIV/AIDS akan menurunkan resiko tertularnya penyakit tersebut. Hal tersebut tidak akan bisa terpenuhi secara keseluruhan jika tidak didukung dengan kesadaran wanita pekerja seks dan kemauan mereka untuk memeriksakan diri atau skrining HIV/AIDS dipelayanan kesehatan terdekat.

\section{KESIMPULAN DAN SARAN Kesimpulan}

1. Pengetahuan wanita pekerja seks tentang HIV/ AIDS cukup baik, dibuktikan dengan para wanita pekerja seks mampu menjelaskan definisi, tanda dan gejala serta cara pencegahan penyebaran HIV/AIDS akan tetapi wanita pekerja seks enggan melakukan pencegahan penyebaran HIV/AIDS.

2. Sebagian besar perilaku wanita pekerja seks mendukung pencegahan penyebaran HIV/AIDS, namun karena faktor kesulitan ekonomi yang melatarbelakangi wanita pekerja seks ini tetap menerima pelanggan yang enggan memakai kondom dan memutuskan tetap menjadi wanita pekerja seks dengan resiko yang ada yaitu penyebaran penyakit HIV/AIDS.

\section{Saran}

\section{Bagi Wanita Pekerja Seks (WPS)}

Wanita Pekerja Seks (WPS) agar senantiasa mencari informasi mengenai penyakit HIV/AIDS untuk dapat mengurangi resiko penularan penyakit tersebut.

\section{Bagi Dinas Kesehatan setempat}

Bagi petugas kesehatan setempat agar melaksanakan penyuluhan maupun kegiatan-kegiatan lainnya yang memberi informasi kepada Wanita Pekerja Seks (WPS) untuk dapat meningkatkan pengetahuan dan dapat memutus mata rantai penularan HIV/AIDS.

\section{Bagi peneliti selanjutnya}

Diharapkan hasil penelitian dapat dijadikan acuan untuk mengembangkan penelitian yang mengkaji tentang banyak pelanggan yang dilayani setiap harinya, karena variabel tersebut dapat dijadikan sebagai acuan untuk mengetahui tingkat penyebaran HIV/AIDS.

\section{DAFTAR PUSTAKA}

Khikam, 2016, Hubungan Peran Perawat Sebagai Konselor Dengan Kepatuhan ODHA Yang Menjalani Terapi ARV Di RSUD KOESMA, 
skripsi Keperawatan, STIKES NU

Tuban, Tuban

Khasanah et al. Upaya Pencegahan Terhadap Penularan HIV/AIDS Dengan Menggunakan Kondom Oleh PSK Di Lokalisasi Kebonsuwung Karanganyar Pekalongan

Karo, 2011, Faktor-Faktor Yang Berhubungan Dengan Perilaku Pencegahan HIV Pada Pekerja Seks Komersial (PSK) Di Kecamatan Patokbeusi Kabupaten Subang

Putra et al. Pengetahuan Dan Upaya Pencegahan IV/AIDS Pada Wanita Pekerja Seksual (WPS) Di Lokalisasi Kuning Semarang, hal. 73

Suyanto, 2010, Perilaku Pekerja Seks Komersial Dalam Penggunaan Kondom Untuk Pencegahan Transmisi HIV/AIDS Di Lokalisasi Teleju Kota Pekanbar, vol. 1, no. 1, hal. 21

Widodo, E 2009, Praktik Wanita Pekerja Seks (WPS) Dalam Pencegahan Penyakit Infeksi Menular Seksual (IMS) Dan HIV\&AIDS Di Lokalisasi Koplak, Kabupaten Grobogan

Arif et al. 2008, Faktor-Faktor Yang Berhubungan Dengan Praktik Wanita Pekerja Seks (WPS) Jalanan Dalam Upaya Pencegahan IMS Dan HIV/AIDS Di Sekitar Alun-Alun Dan Candi Prambanan Kabupaten Klaten, hal. 122

Chandra, R 2012, Hubungan Pengetahuan Dan Sikap Wanita Pekerja Seks Komersial Dengan Tindakan Pencegahan Penyakit Infeksi Menular Seksual (IMS) Di Bandar Baru Kecamatan Sibolangit, skripsi Fakultas Kesehatan Masyarakat, Universitas Sumatera Utara, Medan
Burhan 2011, Analisis Perilaku Seksual Wanita Pekerja Seks (WPS) Penderita Servisitis Gonore (Studi Kasus Pasien Klinik Chrysant Bandung Kabupaten Semarang), skripsi Kesehatan Masyarakat, Universitas Negri Semarang, Semarang

Wilson et al. Gambaran Pengetahuan Wanita Pekerja Seks (WPS) Tentang Penyakit HIV/AIDS Dilokasi Bukit Maraja Desa Marihat Bukit Kecamatan Gunung Maraja Kabupaten Simalungun

Sugiyono, 2012, Metode Penelitian Pendidikan (Pendekatan Kuantitatif, Kualitatif, dan $R \& D)$, Alfabeta, Bandung

Nursalam, 2013, Metodologi Penelitian Ilmu Keperawatan, Edisi 3, Salemba Medika, Jakarta

Sunaryo, 2004, Psikologi Untuk Keperawatan, EGC, Jakarta 